\title{
APPLICATION OF INORGANIC-CONTAMINATED GROUNDWATER TO SURFACE SOILS AND COMPLIANCE WITH TOXICITY CHARACTERISTIC (TCLP) REGULATIONS (U)
}

by

\author{
C. L. Bergren, M. A. Flora
}

Westinghouse Savannah River Company

Savannah River Site Aiken, South Carolina 29808

\section{DISCLAIMER}

This report was prepared as an account of work sponsored by an agency of the United States Government. Neither the United States Government nor any agency thereof, nor any of their employees, makes any warranty, express or implied, or assumes any legal liability or responsibility for the accuracy, completeness, or usefulness of any information, apparatus, product, or process disclosed, or represents that its use would not infringe privately owned rights. Reference herein to any specific commercial product, process, or service by trade name, trademark, manufacturer, or otherwise does not necessarily constitute or imply its endorsement, recommendation, or favoring by the United States Government or any agency thereof. The views and opinions of authors expressed herein do not necessarily state or reflect those of the United States Government or any agency thereor.

This paper was prepared in connection with work done under Contract No. DE-AC09-89SR18035 with the U.S. Department of Energy. By acceptance of this paper, the publisher and/or recipient acknowledges the U.S. Government's right to retain a nonexclusive, royalty-free license in and to any copyright covering this paper, along with the right to reproduce and to authorize others to reproduce all or part of the copyrighted paper. 
Application of Inorganic-Contaminated Ground Water to Surface Soils and Compliance with Toxicity Characteristic (TCLP) Regulations

By C.L. Bergren (1), M.A. Flora (1), J.L. Jackson (2), and E.M. Hicks (2)

\section{ABSTRACT}

The Westinghouse Savannah River Company (WSRC) is currently implementing a Purged Water Management Program (PWMP) at the Savannah River Site (SRS) near Aiken, South Carolina. A variety of constituents and disposal strategies are being considered. Constituents investigated in the PWMP include radionuclides, organics, and inorganics (As, $\mathrm{Ba}, \mathrm{Cd}, \mathrm{Cr}, \mathrm{Pb}, \mathrm{Hg}, \mathrm{Se}$, and $\mathrm{Ag}$ ). One practical disposal alternative is to discharge purged water (all constituents below regulatory levels) to the ground surface near the monitoring well that is being purged. The purpose of this investigation is to determine if long-term application of purged water that contains inorganic constituents (below regulatory levels) to surface soils will result in the accumulation of inorganics such that the soil becomes a hazardous waste according to the Toxicity Characteristic regulations (40 CFR Part 261.24). Two study soils were selected that encompass the range of solls found at the SRS: Lakeland and Orangeburg. Laboratory batch equilibrium studies indicate that the soils, although able to retain a large amount of inorganics, will not exceed Toxicity Characteristic concentrations when subjected to the TCLP. Field studies are underway to confirm this.

(1) Westinghouse Savannah River Company

Building 742-A

Savannah River Site

Aiken, SC 29808

(2) Sirrine Environmental

P.O. Box 24000

Greenville, SC 29616

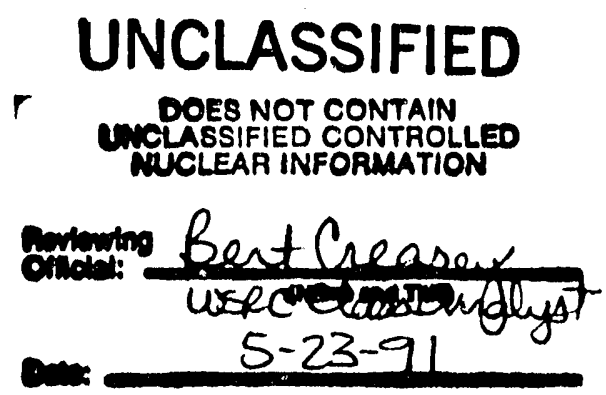




\section{BACKGROUND}

The Westinghouse Savannah River Company (WSRC), operator of the Savannah River Site (SRS) near Aiken, South Carolina, is currently investigating the hydrogeology of the SRS for environmental compliance purposes. Over 1200 monitoring wells have been installed for this investigation. The water removed from a monitoring well prior to sampling is referred to as "purged water." Purged water is normally discharged on the ground surface away from the well from which it was removed. Because purged water may have an impact on the local environment, SRS has, for specific parameters, established specific concentration limits above which purged water may require special hanuling. These concentration limits are referred to as trigger levels.

SRS has established a preliminary plan for managing purged ground water (WSRC, 1990a). This plan includes recommended trigger levels for constituents in purged water. Trigger levels were selected using health-based criteria and regulatory definitions of hazardous waste (e.g., Toxicity Characteristics Leaching Procedure or TCLP). The selection and justification of trigger levels is further discussed in the Purged Water Management Plan (PWMP; WSRC, 1990a).

There are three general categories of contaminants in the PWMP: radionuclides, organics, and inorganics. Specific parameters in each category have trigger levels that govern their disposal. Purged ground water that contains any constituents above the trigger level will be contained and treated to an acceptable level. Purged ground water that does not exceed any trigger levels is discharged directly on the ground surface near the monitoring well.

This project is concerned with proper disposal of inorganic constituents in purged ground water. Recent revisions to 40 CFR Part 261.24 (RCRA) specify eight regulated TCLP inorganic constituents, primarily metals. These inorganics are arsenic (a metalloid), barium, cadmium, chromium, lead, mercury, selenium (a nonmetal), and silver. The TCLP is used to determine the amount of these inorganic constiturnts that can leach out of the parent material 
(e.g., soils, sludges, solids). The concentration in the extracted leachate is determined and then compared to the regulatory level (40 CFR part 261.24; Table 1). If a constituent equals or exceeds the regulatory level, the parent material is considered a characteristic hazardous waste under the RCRA program, and must be handled as a hazardous waste.

The purpose of this study is to determine or predict the long-term effect of applying purged water (in which all eight TCLP inorganics are below regulatory levels) to the soil surface. Because soil has the ability to retain inorganics (e.g., adsorption and precipitation), it is possible that long term application of ground water with low levels of TCLP inorganics could result in the buildup of inorganic constituents at the soil surface. Eventually, the soil could retain enough inorganics such that it failed to meet the TCLP regulatory levels and hence become a hazardous waste.

This study is being conducted in two phases, laboratory and field. The laboratory study was a batch study to determine the capacity of two study soils to retain TCLP inorganics. The field study is being conducted using purged water at two study sites at the SRS. We did not intend to (a) perform adsorption isotherms and determine equilibrium distribution coefficients (Kd), (b) discern the retention mechanism (e.g., adsorption, precipitation, complexation), (c) determine the transport rate of TCLP inorganics through the vadose zone, or (d) predict the impact on ground water of TCLP inorganics.

\section{METHODS}

Following is a discussion of the (a) selection and sampling of the soil study sites, (b) selection and sampling of the purged water monitoring well, (c) laboratory study, and (d) field study.

\section{Selection and Sampling of Study Sites}

Two soil types were selected that generally encompassed the range of physical and chemical properties of soils typically found at the SRS. The results from an extensive soils study 
conducted at the SRS was examined to aid in selection of study soils (WSRC, 1990b).

One of the more significant parameters affecting inorganics (i.e., metals) fate in soils is cation exchange capacity (CEC). CEC is the sum total of exchangeable cations that a soil can adsorb and is a function of soil texture, $\mathrm{pH}$, organic matter content, and within a given soil texture, the amount and type of clay (Rhoades, 1982). Other factors being equal, soils with a high clay content (USDA soil classification system) typically have a medium to high CEC while soils that are predominantly sand have a low CEC. Both types of soil profiles are found at SRS. The range of responses of soils to inorganics-bearing water (e.g., the TCLP metals) were met by selecting a soil profile that contained a significant amount of clay and a profile that contained a significant amount of sand.

General soil horizon descriptions, based on USDA soil classification, were examined to aid in the selection of study soils. In addition, the general occurrence and location of the soils at SRS were also considered. After review of SRS soil data, the two soil types selected were the Lakeland (sand) and Orangeburg (sand/sandy clay; WSRC, 1990b). Soil descriptions are provided in Tables 2 and 3. Because of the extremely sandy, highly permeable, and pedogenically undeveloped character of the Lakeland soil profile, it is highly infertile and droughty. As a result, Lakeland soils generally support an ecosystem tolerant of these conditions, such as scrub oaks and lichens. Soil was collected from 0-8 inches $(0-20 \mathrm{~cm})$ below the surface and at 30-36 inches $(76-91 \mathrm{~cm})$ below the surface at the Lakeland site. The Orangeburg site is in a planted pine forest. Compared to the Lakeland soils, the Orangeburg soils are better for agricultural and silvaculture use because of the better fertility and availability of water. Soll was collected from 0-6 inches $(0-20 \mathrm{cri})$ and at 30-36 inches $(76-91 \mathrm{~cm})$. Chemical and physical characteristics of the study soils are provided in Tables 4 and 5.

Approximately $20 \mathrm{~kg}$ of each soil type (10 kg of surface soil, $10 \mathrm{~kg}$ of subsurface soil) was collected at each site. Soil was collected and transported in one gallon plastic bags. A sample of each soil horizon was analyzed for the following: $\mathrm{pH}$, moisture content, bulk 
density, particle density, total $\mathrm{CEC}$, total $\mathrm{As}, \mathrm{Ba}, \mathrm{Cd}, \mathrm{Cr}, \mathrm{Pb}, \mathrm{Hg}, \mathrm{Ag}, \mathrm{Se}, \mathrm{Al}, \mathrm{Be}, \mathrm{Ca}, \mathrm{Cu}, \mathrm{Fe}$, $\mathrm{Li}, \mathrm{Mg}, \mathrm{Mn}, \mathrm{Ni}, \mathrm{K}, \mathrm{Na}, \mathrm{Zn}$, and TCLP inorganics after the TCLP extraction.

\section{Selection and Sampling of the Purged Water Monitoring Well}

A monitoring well was selected that (1) contained ground water with relatively high concentrations of TCLP inorganics but with concentrations below trigger levels, (2) was capable of providing the quantities of water required by the lab and field studies, and (3) was easily accessible to sampling personnel. After a review of a SRS monitoring well inventory, monitoring well DCB-1A was selected. Chemical characteristics of this water are provided in Table 1. Note that the inorganic TCLP constituents, in spite of their elevated levels, are orders of magnitude lower than the trigger levels.

In addition to the relatively low $\mathrm{pH}$ and high metals concentrations, DCB-1A ground water has elevated levels of sulfate (Table 1). Sulfate concentrations ranged from 540 to $8300 \mathrm{mg} / \mathrm{L}$ with an arithmetic average of $4700 \mathrm{mg} / \mathrm{L}$. The effect of elevated sulfate on the formation of insoluble precipitates will be further discussed in the Results and Discussion section.

Approximately 340 liters ( 90 gallons) of DCB-1A well water was collected for the laboratory study. DCB-1A water was slightly turbid with a yellow-orange cast to it, even after purging the well with the dedicated submersible pump. The historical $\mathrm{pH}$ of the purged water from DCB-1A is approximately 2.5. Water was collected and transported in polyethylene containers.

After the water was transported to the treatability laboratory, the concentrations of TCLP inorganics were increased to the trigger levels (Table 1 ) by adding the appropriate inorganic TCLP constituent in a water soluble form (i.e., silver nitrate to raise the dissolved silver concentration). The entire batch of spiked water was mixed at the same time in a 50 liter polyethylene carboy. This water is referred to as spiked DCB-1A water. Addition of the inorganic stock solutions caused the formation of white, cloudy precipitates (further discussed 
in the Results and Discussion section). Prior to sampling or use of the water, the 50 liter carboy was thoroughly mixed to resuspend any precipitated materials.

\section{Laboratory Study}

Batch studies were conducted for each of the two study soils to determine the amount of TCLP inorganics that they were capable of retaining (e.g, adsorption). CEC data from a previous study (WSRC, 1990b) were used to design the batch experiments. According to that study, CEC for the Orangeburg soil averaged $6 \mathrm{meq} / 100$ grams while the Lakeland was 3 meq/100 grams (WSRC, 1990b). It was estimated that 300 grams of Lakeiand soil would require about 2.5 liters of purged water (with TCLP inorganics concentrations at trigger levels) to equal maximum adsorption capacity. The Orangeburg soll, because of its greater CEC, was estimated to require twice as much purged water (5 liters) per 300 grams of soil to achieve maximum inorganics adsorption. Thus, we decided to use 4 and 8 liters of spiked DCB-1A water per 300 grams of the study soil.

Selection of an equilibrium time is difficult for a complex system such as soil, inorganics, and water. Adsorption is generally regarded as a fast reaction. Solute (e.g., metals) adsorption processes are ofien initially rapid, while further reduction in solute concentration continues at a decreasing rate, asymptotically approaching a constant concentration.

Based on these considerations, the Environmental Protection Agency (EPA) has suggested an operational definition of equilibrium for soil/water adsorption studies (EPA, 1987). This operational definition of equilibrium time is the minimum amount of time needed to establish a rate of change of the solute concentration in solution equal to or less than $5 \%$ per 24 -hour interval. Studies conducted and reviewed by the EPA have shown that 24 to 48 hours are often adequate to meet this operational definition of equilibrium. The American Society for Testing and Materials (ASTM) Method 4319 specifies a minimum contact time of 3 days and a maximum of 14 days or longer (ASTM, 1991). Soils and spiked purged water in this study, therefore, were continuously mixed for approximately two weeks. 
A straight factorial experimental design was employed: two solls, two horizons, and two soil/water mixture ratios (i.e., 8 combinations). Three hundred grams of surface and subsurface Lakeland and Orangeburg soils were each added to four and eight liters of spiked DCB-1A ground water. Thus, there were eight combinations of soil and water. For example, the Lakeland experimental series was:

- Lakeland 0-8 inch soll with 4 liters of spiked water

- Lakeland 0-8 inch soll with 8 liters of spiked water

- Lakeland 30-36 inch soil with 4 liters of splked water

- Lakeland 30-36 inch soll with 8 liters of spiked water.

Soil was not dried prior to use. Soll and water were mixed in 4 liter polyethylene, wide mouth jars. For the 8 liter volumes, 150 grams of soll was placed with 4 titers of spiked water in a polyethylene jar. After mixing, the $\mathrm{pH}$ of the resultant soil/water mixture was adjusted to 6.5 with $4 \mathrm{~N} \mathrm{NaOH}$. The soll/water mixtures were placed on a rotary extractor at $30 \mathrm{rpm}$ and the $\mathrm{pH}$ periodically adjusted to 6.5 with either $4 \mathrm{~N} \mathrm{NaOH}$ or $2 \mathrm{~N} \mathrm{HCl}$.

$\mathrm{A} \mathrm{pH}$ of 6.5 , although higher than the soil $\mathrm{pH}$ (approximately 5.0 for both soil types), was selected as a worst case scenario. The TCLP metals $(\mathrm{Ba}, \mathrm{Cd}, \mathrm{Cr}, \mathrm{Hg}, \mathrm{Pb}, \mathrm{Ag})$ are less soluble at a pH of 6.5 versus 5.0 (GEOCHEM; Sposito and Mattigod, 1980). We reasoned that at a lower solubility (higher $\mathrm{pH}$ ), there was a greater chance that the TCLP metals would be retained by the soil and thus approach the regulatory level when subjected to the TCLP test. Arsenic (metalloid) and selenium (nonmetal) do not necessarily behave the same as the TCLP metals. For example, pentavalent arsenic adsorption has been shown to be greater at lower $\mathrm{pH}$ values (EPA, 1987). Adsorption of trivalent arsenic, used in these experiments, was not $\mathrm{pH}$ dependent from $\mathrm{pH} 4$ to 10 (EPA, 1987).

At the completion of the mixing, the containers were allowed to stand undisturbed for at least 48 hours. The supernatant was decanted from the soil, filtered $(0.45$ micron), and submitted 
for total TCLP inorganics analysis to determine the dissolved concentrations of TCLP inorganics remaining in the supernatant.

Soil was vacuum filtered through $15 \mathrm{~cm}$ diameter filter paper (Whatman 41) to remove as nuch of the water as possible. Samples of the soll were submitted for total and TCLP inurganics analysis. This step collected both adsorbed and precipitated TCLP inorganics, sinillar to the application of purged water to the soll surface at a monitoring well.

\section{Field Study}

A field study is being conducted to better predict the effect of long-term application of purged water on SRS soils. Test plots were not disturbed (e.g., graded, vegetation removed) prior to application of purged water. Basically, the field study involves the stepped-up application rate of unspiked DCB-1A ground water to the study plots. Many monitoring wells at SRS are sampled every 3 months or less frequently. Thus, application of purged water at those wells occurs at most 4 times per year. The field study involves application of purged water on a weekly basis, or 13 times more frequently than the most heavily sampled monitoring wells.

DCB-1A water is uniformly applied to the test plots by pouring water into high density

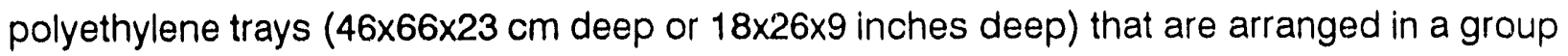
over the study plots. Each group of trays is 8 trays long ( $429 \mathrm{~cm}$ or 169 inches) by 2 trays wide (137 cm or 54 inches). Application area for the field plots is therefore 5.9 square meters (63 square feet). The trays are supported by a PVC pipe rack such that the bottom of the trays are approximately $10 \mathrm{~cm}$ (4 inches) above the ground surface. Each tray has 12 evenly spaced $3 / 32$ inch $(2.4 \mathrm{~mm})$ diameter holes in the bottom to allow the purged water to slowly flow out onto the study plot. For each application of purged water, 9.5 liters ( 2.5 gallons) of freshly collected DCB-1A water is poured into each plastic tray (described above). This results in an application rate of $2.5 \mathrm{~cm}$ (1 inch) of purged water per study plot per week. Time to empty a tray is about 15 minutes. Runoff of water on the ground surface is minimal. 
If the ground appears to be hydrophobic (l.e., dry), potable water is first applied as a fine mist to wet the soil and hence reduce runoff from under the trays.

Surface and shallow subsurface samples will be collected after approximately 3, 6, and 12 months of weekly application. Soil samples will be analyzed for total TCLP inorganics and TCLP inorganics after the TCLP extraction.

\section{RESULTS AND DISCUSSION}

\section{Water Data}

\section{Comparison of Spiked Water to Targeted Trigger Levels}

DCB-1A ground-water data are summarized in Table 1. Spiked water was analyzed to ensure that the TCLP inorganics were added such that their concentrations were at the trigger levels. The inorganics concentrations are close to the targeted trigger levels for arsenic, cadmium, chromium, selenlum, and silver (Table 1). There is reasonably good agreement for lead and mercury.

The barium data, however, suggest that little or no barium was added to the DCB-1A water during spiking. Barium in the spiked water was analyzed by two laboratories to confirm these data. However, examination of barium data for soils after reaction with the spiked water (Tables 4 and 5 ) indicates that the barium was added to the spiked water. A mass balance for barium was done for each of the 8 combinations of study soil as follows:

\begin{tabular}{|c|c|c|c|c|c|c|}
\hline $\begin{array}{l}\text { Init. Ba } \\
\text { in Soil } \\
\text { (unreacted) }\end{array}$ & + & $\begin{array}{l}\text { Init. Ba } \\
\text { in Water } \\
\text { (spiked) }\end{array}$ & $=$ & $\begin{array}{l}\text { Final Ba } \\
\text { in Soil } \\
\text { (reacted) }\end{array}$ & + & $\begin{array}{l}\text { Final } \mathrm{Ba} \\
\text { in Water } \\
\text { (supernatant) }\end{array}$ \\
\hline
\end{tabular}

The unknown term was assumed to be the initial barium in the spiked water (second term). Since there are data for the other 3 terms, it was possible to back-calculate the theoretical concentration of barium in the spiked water. The arithmetic average concentration was calculated as $143 \mathrm{mg} \mathrm{Ba} / \mathrm{L}$ for all eight combinations of study soil, or $105 \mathrm{mg} \mathrm{Ba} / \mathrm{L}$ if the 
datum for the Orangeburg 30-36 inch, eight liter combination was excluded. These backcalculated values agree closely with the targeted TCLP trigger level of $100 \mathrm{mg} \mathrm{Ba} / \mathrm{L}$.

The GEOCHEM model (Sposito and Mattigod, 1980) was run to determine the speciation of barium at pH 2 and 6.5 using the constituents of spiked DCB-1A water as input. GEOCHEM is a thermodynamic model that predicts the speciation of metals in soil solutions and other natural water systems based on data inputs and model assumptions. At both $\mathrm{pH}$ values and with an average sulphate concentration of $4700 \mathrm{mg} / \mathrm{L}$ in DCB-1A water, barium was predicted to be a solid (barium sulfate): This may account for the laboratory errors in analyzing total barium. Prior to analysis, an allquot of spiked DCB-1A water was sampled by thoroughly mixing the spiked DCB-1A water in a 50 liter preparation carboy. Concentrated nitric acid was added to this sample to give a final pH of less than 2. However, barium sulfate is a solid even at $\mathrm{pH} 2$. The two laboratories then filtered the sample or took an aliquot of the sample supernatant prior to analysis. In either case, barium concentration would have been significantly underestimated since most of the barium remained in the sample container as a solid. Soil samples, however, were subjected to a thorough digestion with concentrated acid and heat prior to analysis. This would explain why the barium was detected in the soil samples but not in the spiked water sample. Thus, it is evident that the correct concentration of barium was added to the spiked DCB-1A water prior to reacting the water with the study soils.

\section{Soil Data}

Tables 4 and 5 present the data for initial (unreacted) and final (reacted) soil. Data are provided for both four and eight liters of spiked DCB-1A water that was reacted with 300 grams of study soil (Lakeland or Orangeburg). Following is a discussion of the soils data.

\section{Comparison of Total TCLP Inorganics with TCLP Data}

As seen in Tables 4 and 5, all inorganic TCLP constituents in unreacted and reacted soils were below detection limits when the TCLP was performed on the soil. In addition, these detection limits are considerably less than the TCLP trigger levels. Total inorganics analyses 
on the TCLP inorganic constituents, however, revealed that the reacted solls retained significant amounts of TCLP inorganics.

Twn major mechanisms are involved in the retention of metals by solls: adsorption and precipitation (Evans, 1989). Inorganics in the study solls were adsorbed to the soll or were not soluble enough (e.g., precipitated) such that the extraction procedure (TCLP) removed detectable quantities.

The mass of TCLP constituents from spiked DCB-1A water that were retained by the solls are orders of magnitude greater than the mass received by an experimental plot over many applications. Table 6 presents estimates for the number of applications that would have to be done for an experimental fleld plot to retain an equal concentration of inorganics as retained in the laboratory experiments. It is assumed that all of the TCLP inorganics are retained by the upper 3 inches of soll. From Table 6, thousands of applications of purged DCB-1A water would be necessary for the field plots to retain TCLP inorganics at the same concentration as the laboratory experiments. Recall that all TCLP constituents in the reacted laboratory soils were below detection limit (below regulatory levels) when subjected to the TCLP extraction and analysis (Tables 4 and 5). Furthermore, the reacted soil was kept at a $\mathrm{pH}$ of 6.5 while the field plots have a natural pH of around 5. Most of the TCLP inorganic constituents are most likely more mobile at the lower $\mathrm{pH}$ found in the soll ( $\mathrm{pH} 5$ ). Thus, in the field plots, metals would be expected to migrate downward and not accumulate at the surface to the extent that the laboratory data indicate.

For these reasons, Lakeland and Orangeburg field plots are predicted not to exceed TCLP regulatory levels after repeated application of inorganics-contaminated ground water. Furthermore, soll adjacent to SRS monitoring wells that receive purged water will most likely not accumulate inorganics such that they become a hazardous waste according to the RCRA TCLP definition. 


\section{Comparison of Total Cation Exchange Capacities (CECs)}

Initial data indicated that the CECs were 3 and 6 meq/100 grams for the Lakeland and Orangeburg soils, respectively (WSRC, 1990b). However, CEC data from this study were two to three times lower (Tables 4 and 5). The highest CEC and clay content was in the subsurface (30-36 inches) Orangeburg soil with a total CEC of $3.5 \mathrm{meq} / 100 \mathrm{grams}$. The total CEC for both the Lakeland and Orangeburg surface soils (0-8 inches) was 0.9 meq/100 grams. The Lakeland subsurface soil had a total CEC of $0.7 \mathrm{meq} / 100$ grams.

\section{Comparison of Initial, 4-Liter, and 8-Liter Data}

The intent of the laboratory experiment was to react the study soils with a large mass of TCLP constituents and then determine if the soil would still pass the TCLP test. As discussed, we did not intend to perform adsorption isotherms and determine equilibrium adsorption coefficients $(\mathrm{Kd})$.

Final concentrations of inorganics in the surface Lakeland soil were similar between the 8 and 4 liter combinations. Results for the subsurface Lakeland and the surface Orangeburg soils indicate that the concentration of inorganics in the 8 liter reactors was about two times greater than those in the 4 liter reactors. The soil able to retain the greatest mass of TCLP inorganics was the Orangeburg subsurface soil. The 8 liter reactor results for total inorganics was generally 3 to 4 times higher than the totals for the 4 liter reactor. The mechanism of inorganics retention was not determined.

\section{Comparison of Total Inorganics Between the Surface Soils}

The concentration of inorganics retained by the Lakeland and the Orangeburg soils is similar (Tables 4 and 5). This is expected since both surface soils have similar chemical and physical properties (e.g., CEC of $n .9$ and primarily composed of sand).

\section{Comparison of Total Inorganics Between the Subsurface Soils}

With the exception of aluminum and iron, the Orangeburg subsurface soil retained from two to five times more inorganics than the Lakeland subsurface soil. The CEC for the Lakeland 
and Orangeburg subsurface soils are 0.7 and 3.5 meq/100 grams, respectively, or a factor of five difference. Thus, the difference in inorganics retention is in large part attributable to the higher adsorption capacity of subsurface Orangeburg soil, as indicated by CEC.

The subsurface Lakeland soil retained only slightly more inorganics than the surface Lakeland and Orangeburg soil, with the exception of aluminum and iron. Aluminum and iron data are not representative of what the soils retained. This is most likely due to the total inorganics analytical procedure that resulted in dissolution of the soil matrix that is composed in large part of aluminum and iron. 


\section{CONCLUSIONS}

The following conclusions were made:

(1) The study soils are capable of retaining (adsorption and precipitation) a relatively large amount (up to several thousand parts per million) of inorganic constituents, including the TCLP inorganics.

(2) In spite of the soils ability to retain relatively large amounts of inorganics, the soils did not exceed TCLP regulatory levels when subjected to the Toxicity Characteristics Leaching Procedure (TCLP).

(3) Lakeland and Orangeburg surface soils both retained approximately the same amount of inorganics.

(4) The subsurface Lakeland soil retained only slightly more inorganics than the surface Lakeland and Orangeburg soil.

(5) The subsurface Orangeburg soil retained the greatest amount of inorganic constituents, the increased retention presumeably due to adsorption since it had the highest CEC.

(6) Lakeland and Orangeburg field plots will not exceed TCLP regulatory levels after repeated application of inorganics-contaminated ground water.

(7) Soil adjacent to SRS monitoring wells that receive purged water will not accumulate inorganics such that they become a hazardous waste according to the RCRA TCLP definition.

(8) Field experiments are currently being conducted to confirm laboratory studies.

\section{ACKNOWLEDGEMENTS}

This paper was prepared in connection with work done under Contract No. DE-AC099 8BSR18035 with the Department of Energy. The authors thank Mr. Virgil Rogers (WSRC) for help with soil selection and classification, Ms. Teresa Jordan (WSRC) and Mr. Sean Asquith (Sirrine) for assistance with field work, and Dr. David Hargett for review. 


\section{REFERENCES}

ASTM, 1991. American Society for Testing and Materlals. "1991 Annual Book of ASTM Standards, Vol. 04.08, Method D 4319-83, "Standard Test Method for Distribution Ratios by the Short-Term Batch Method", pp. 619-624.

EPA, 1987. United State Environmental Protection Agency (USEPA). "Batch-Type Adsorption Procedures for Estimating Soil Attenuation of Chemicals." Draft Technical Resource Document for Public Comment. USEPA Office of Research and Development, Cincinnati, Ohio. EPA/530-SW-87-006 (NTIS No. PB87-146155).

Evans, 1989. L.J. Evans, "Chemistry of Metal Retention by Soils." Environmental Science and Technology Vol. 23, No. 9, pp. 1046-1056.

Rhoades, 1982. J.D. Rhoades. "Cation Exchange Capacity." In "Methods of Soil Analysis, Part 2--Chemical and Microbiological Properties, Second Edition", A.L. Page, Editor. American Society of Agronomy and Soll Science Soclety of America, Madison, Wisconsin.

Rogers, 1990. V.A. Rogers. "Soil Survey of Savannah River Plant Area, Parts of Aiken, Barnwell, and Allendale Counties, South Carolina." USDA, June, 1990.

Sposito and Mattigod, 1980. G. Sposito and S.V. Mattigod, "GEOCHEM: A Computer Program for the Calculation of Chemical Equilibria in Soil Solutions and Other Natural Water Systems." Dept. of Soll and Environmental Sciences, University of California, Riverside.

WSRC, 1990a. Westinghouse Savannah River Company. "Purged Water Management Plan." Prepared for Westinghouse Savannah River Company by Sirrine Environmental Consultants, April 1990.

WSRC, 1990b. Westinghouse Savannah River Company. "Geochemical and Physical Properties of Solls and Shallow Sediments at the Savannah River Plant (U)." WSRC-RP-901031. August, 1990 . 


\begin{tabular}{|c|c|c|c|c|c|c|}
\hline \multicolumn{7}{|c|}{$\begin{array}{l}\text { Table 1. Summary of DCB-1A Well Water Data (PWMP) } \\
\text { Prepared for the Westinghouse Savannah River Company (WSRC), Aiken, SC } \\
\text { by Sirrine Environmental Consultants, Greenville, SC }\end{array}$} \\
\hline \multirow{2}{*}{ Parameter } & \multicolumn{4}{|c|}{ Initial Concentrations } & \multirow{2}{*}{$\begin{array}{l}\text { Conc. } \\
\text { After } \\
\text { Spiking }\end{array}$} & \multirow{2}{*}{$\begin{array}{l}\text { Trigger } \\
\text { Level, } \\
40 \text { CFR, } \\
261.24\end{array}$} \\
\hline & \multicolumn{2}{|c|}{ Historical SRS Data } & Mean & $\begin{array}{l}9 / 1990 \\
\text { Data }\end{array}$ & & \\
\hline \multicolumn{7}{|c|}{ TCLP Inorganics (mg/L) } \\
\hline As (total) & $0-0.270$ & 4 & 0.070 & $<0.005$ & 5.1 & 5 \\
\hline $\mathrm{Ba}$ (total) & $0.010-0.050$ & 7 & 0.018 & 0.015 & $0.35(1)$ & 100 \\
\hline Cd (total) & $0.018-0.091$ & 11 & 0.033 & 0.019 & 1.0 & 1 \\
\hline $\mathrm{Cr}$ (total) & $0.020-0.240$ & 11 & 0.140 & 0.084 & 4.7 & 5 \\
\hline $\mathrm{Pb}$ (total) & $0.010-0.310$ & 11 & 0.080 & $<0.150$ & $1.5(1)$ & 5 \\
\hline $\mathrm{Hg}$ (total) & $0.0001-0.00074$ & 11 & 0.0003 & 0.0005 & $0.14(1)$ & 0.2 \\
\hline Se (total) & $0.002-0.027$ & 10 & 0.008 & $<0.025$ & 0.89 & 1 \\
\hline $\mathrm{Ag}$ (total) & $0.001-0.039$ & 10 & 0.012 & $<0.025$ & 4.0 & 5 \\
\hline \multicolumn{7}{|l|}{ Other Metals (mg/L) } \\
\hline Alumimum & 500 & 1 & 500 & 340 & 300 & $N A$ \\
\hline Beryllium & $0.03-0.11$ & 9 & 0.07 & $<0.1$ & $<0.1$ & NA \\
\hline Calcium & ND & ND & ND & 210 & 190 & NA \\
\hline Copper & $0.2-1.8$ & 10 & 0.8 & 1 & 0.59 & NA \\
\hline Iron & $10-1750$ & 11 & 420 & 100 & 100 & NA \\
\hline Lithlum & 0.55 & 1 & 0.55 & $<0.5$ & $<0.5$ & NA \\
\hline Magnesium & $70-425$ & 3 & 230 & 180 & 160 & NA \\
\hline Manganese & $10-50$ & 11 & 26 & 25 & 22 & NA \\
\hline Nickel & $0-7.5$ & 10 & 2.7 & 2.3 & 2.1 & NA \\
\hline Potassium & $0.66-2.5$ & 2 & 1.6 & $<2.0$ & 3.4 & NA \\
\hline Sodium & $12-34$ & 7 & 21 & 20 & 18 & NA \\
\hline Zinc & $0-12$ & 10 & 6 & 5.3 & 4.8 & NA \\
\hline \multicolumn{7}{|l|}{ Anions (mg/L) } \\
\hline Chloride & $1.5-18$ & 7 & 7.3 & ND & ND & NA \\
\hline Fluoride & $<0.1-14.2$ & 8 & 3.9 & ND & ND & NA \\
\hline Nitrate (as N) & 0.27 & 1 & 0.27 & ND & ND & $10,000(2)$ \\
\hline Phosphates (total) & 0.04 & 1 & 0.04 & ND & ND & NA \\
\hline Sulfate & $540-8300$ & 15 & 4700 & ND & ND & NA \\
\hline
\end{tabular}

Notes:

PWMP $=$ Purged Water Management Program

NA $=$ Not Applicable

ND $=$ Not Determined

(1) = Average of data from two laboratories

(2) = Proposed trigger level for nitrate (WSRC, 1990a) 
The Lakeland series consists of excessively drained, rapidly permeable soils that formed in sandy marine sediment on the Coastal Plain and in areas intermingled with the Sand Hills. These soils are on broad ridges and side slopes. Slopes range from 0 to 10 percent. Lakeland solls are classified as thermlc, coated Typic Quartzipsamments.

Lakeland solls are on the same general landscape as Blanton, Troup, Fuquay, Wagram, and Lucy soils. The associated soils have a Bt horizon.

Typical pedon of Lakeland sand, 0 to 6 percent slopes:

Ap - 0 to 3 inches, 0 to 8 centimeters; yellowish brown (10YR 5/4) sand; single grained; loose; few fine and medlum roots; very strongly acid; abrupt wavy boundary.

C1 - 3 to 50 inches, 8 to 127 centimeters; very pale brown (10YR 7/4) sand; single grained; loose; few fine and medium roots; most sand grains coated; strongly acid; gradual wavy boundary.

C2 - 50 to 60 inches, 127 to 152 centimeters; light yellowish brown (10YR 6/4) sand; single grained; loose; about 15 percent clean sand grains; strongly acid; gradual wavy boundary.

C3 - 60 to 80 inches, 152 to 203 centimeters; very pale brown (10YR 7/4) sand; loose; about 20 percent clean sand grains; few coarse sand grains and small pebbles; moderately acid.

The thickness of the sandy layers is more than 80 inches. The solls are moderately acid to very strongly acid throughout.

From Rogers, 1990. 


\section{Table 3. Orangeburg Series}

The Orangeburg series consists of well drained, moderately permeable soils that formed in loamy marine sediment on the Coastal Plain. These soils are on broad ridgetops; moderately long, smooth side slopes; and gently rolling breaks below gentle side slopes and nearly level ridgetops. Slopes range from 0 to 10 percent. Orangeburg soils are classified as fine-loamy, siliceous, thermic Typic Paleudults.

Orangeburg solls are on the same general landscape as Alley, Dothan, Fuquay, Lucy, Norfolk, Vaucluse, and Wagram solls. Alley, Fuquay, Lucy, and Wagram soils are in the arenic subgroup. Norfolk solls have a yellowish brown subsoil. Dothan and Fuquay soils have over 5 percent nodules of plinthite in the subsoil. Vaucluse and Alley soils have brittle and cemented layers in the subsoil. They are on the complex slope breaks.

Typical pedon of Orangeburg loamy sand, 2 to 6 percent slopes:

Ap - 0 to 6 inches, 0 to 15 centimeters; dark yellowish brown (10YR 4/4 loamy sand; weak medium granular structure; very friable; common fine roots; very strongly acid; abrupt wavy boundary.

Bt1 - 6 to 10 inches, 15 to 25 centimeters; yellowish red (5YR 4/6) sandy loam; weak medium subangular blocky structure; very friable; few faint clay films on faces of peds; few fine, medium, and large roots; very strongly acid; gradual wavy boundary.

Bt2 - 10 to 17 inches, 25 to 43 centimeters; yellowish red (5YR 5/6) sandy loam; weak medium subangular blocky structure; friable; few faint clay films on faces of peds; common fine and few medlum and large roots; very strongly acid; gradual wavy boundary.

Bt3 - 17 to 33 inches, 43 to 84 centimeters; yellowish red (5 YR 4/6) sandy loam; weak medium and coarse subangular blocky structure; friabie; common faint clay films on faces of preds; common fine and few medium roots; few fine holes; very strongly acid; diffuse smeroth boundary.

Bt4 . 33 to 56 inches, 84 to 142 centimeters; red (2.5YR 4/8) sandy clay loam; weak coarse subangular blocky structure; friable; common faint clay films on faces of peds; few medium roots; few fine holes; very strongly acid; gradual wavy boundary.

Bt5 - 56 to 62 inches, 142 to 157 centimeters; red (2.5 YR 4/8) sandy clay loam; few fine prominent strong brown (7.5 YR 5/6) mottles; weak coarse subangular blocky structure; friable; common faint clay films on faces of peds; few small pebbles of quartz; very strongly acid.

From Rogers, 1990. 
Tablo 4. Lakoland Soll (Sand) Data Summary (PWMP)

Prepared lor the Westinghouse Savannah River Company (WSRC), Alken, SC

by Slirine Envitonmental Consultants, Greenville, SC

\begin{tabular}{|l|lll}
\hline & Lakeiand Soll $0-8^{\prime \prime}$ & \\
& & & \\
Palameter and & & Final & Final \\
Regulatory & Inillal & Conc. & Conc. \\
Levol (mg/L) & Conc. & (4L H2O) & (8L H2O)
\end{tabular}

TCLP Inorganics (TCLP inorganlos analyals; $\mathrm{mg} / \mathrm{h}$ )

\begin{tabular}{|c|c|c|c|c|c|c|}
\hline At $(5.0)$ & $<0.005$ & $<1.0$ & $<1.0$ & $<0.005$ & $<1.0$ & $<1.0$ \\
\hline $\mathrm{Ba}(100.0)$ & 0.248 & $<1.0$ & $<1.0$ & 0.204 & $<1.0$ & $<1.0$ \\
\hline$C d(1.0)$ & $<0.005$ & $<0.5$ & $<0.5$ & $<0,005$ & $<0.5$ & $<0.5$ \\
\hline $\operatorname{Cr}(5.0)$ & $<0.008$ & $<1.0$ & $<1.0$ & $<0.008$ & $<1.0$ & $<1.0$ \\
\hline $\mathrm{Pb}(5.0)$ & $<0.030$ & $<1.0$ & $<1.0$ & $<0.030$ & $<1.0$ & $<1.0$ \\
\hline $\mathrm{Hg}_{\mathrm{g}}(0.2)$ & $<0,002$ & $<0.2$ & $<0.2$ & $<0.002$ & $<0.2$ & $<0.2$ \\
\hline Se (1.0) & $<0.005$ & $<0.5$ & $<0.5$ & $<0.005$ & $<0.5$ & $<0.5$ \\
\hline$A g\langle 5.0\rangle$ & $<0,005$ & $<1,0$ & $<1.0$ & $<0.005$ & $<1,0$ & $<1.0$ \\
\hline
\end{tabular}

TCLP Inorganlas (total Inorganlos analyals; mg/kg)

\begin{tabular}{|l|l|l|l|}
\hline As (total) & $<0.603$ & 69 & 107 \\
\hline Ba (total) & 11.1 & 1600 & 2500 \\
\hline $\mathrm{Cd}$ (total) & $<0.301$ & 15 & 23 \\
\hline $\mathrm{Cr}$ (total) & 2.55 & 79 & 117 \\
\hline $\mathrm{Pb}$ (total) & 3.22 & 298 & 84 \\
\hline $\mathrm{Hg}$ (total) & $<0.100$ & 1.4 & 4.0 \\
\hline $\mathrm{Se}$ (total) & $<0.301$ & 13 & 21 \\
\hline Ag (total) & $<0.301$ & 72 & 109 \\
\hline
\end{tabular}

\section{Lakeland Soil 30-36"}

Final Final

Inltial Conc. Conc

Conc. (4L H2O) (8L H2O)

\begin{tabular}{|c|c|c|c|c|c|c|}
\hline Aluminum & 2900 & 9700 & 1200 & 3700 & 8800 & 14000 \\
\hline Berylllum & $<1.0$ & $<1.0$ & $<1,0$ & $<1.0$ & $<1.0$ & 2.1 \\
\hline Calclum & 26 & 420 & $\overline{332}$ & 38 & 190 & 270 \\
\hline Copper & 1.4 & 12 & $\sqrt{17}$ & 1.3 & 9.5 & 18 \\
\hline Iron & 1700 & 3700 & 4201 & 2200 & 3600 & 5400 \\
\hline Lithlum & 1.23 & 7.3 & 9.2 & 1.8 & 6.4 & 11 \\
\hline Magneslum & 82 & 580 & 510 & 151 & 450 & 680 \\
\hline Manganeso & 30 & 190 & 180 & 15 & 110 & 210 \\
\hline Niokel & 1.1 & 37 & 56 & 2.2 & 31 & 64 \\
\hline Potassium & 48 & 78 & 55 & 78 & 82 & 122 \\
\hline Sodlum & $<110$ & 700 & 1000 & 1.5 & 570 & 860 \\
\hline$Z \ln 0$ & 5.6 & 89 & 132 & 5.1 & 73 & 147 \\
\hline
\end{tabular}

Other Analyses

\begin{tabular}{|l|l|l|}
\hline$<0.432$ & 54 & 123 \\
\hline 14.6 & 1300 & 2900 \\
\hline$<0.216$ & 12 & 24 \\
\hline 3.52 & 64 & 135 \\
\hline$<1.29$ & 51 & 105 \\
\hline$<0.100$ & 1.4 & 1.6 \\
\hline$<0.216$ & 11 & 24 \\
\hline$<0.216$ & 57 & 126 \\
\hline
\end{tabular}

\begin{tabular}{|c|c|c|c|c|c|c|}
\hline $\mathrm{pH}$ & 4.9 & 6.55 & 6.45 & 5.0 & 6.53 & 6.53 \\
\hline CEC $(m e q / 100 g)$ & 0.3 & NA & NA & 0.3 & $\mathrm{NA}$ & $N A$ \\
\hline $\begin{array}{l}\text { Total CEC } \\
(\mathrm{meq} / 100 \mathrm{~g})\end{array}$ & 0.9 & NA & NA & 0.7 & NA & NA \\
\hline$\%$ org. mattor & 2.0 & NA & NA & $<0.1$ & NA & NA \\
\hline Percent Sand(1) & 98 & NA & NA & 92 & NA & NA \\
\hline Percenl Silt(1) & 0 & NA & NA & 6 & NA & NA \\
\hline Percent Clay (1) & 2 & NA & NA & 2 & NA & NA \\
\hline $\begin{array}{l}\text { Dry Blk Density } \\
\text { (g/cu cm) }\end{array}$ & 1.33 & NA & NA & 1.54 & NA & NA \\
\hline $\begin{array}{l}\text { Particle } \\
\text { Donsity } \\
(\mathrm{g} / \mathrm{cu} \mathrm{cm})\end{array}$ & 2.53 & NA & NA & 2.60 & NA & NA \\
\hline $\begin{array}{l}\text { Gravimetric } \\
\text { Molsture \% }\end{array}$ & 2.21 & 32.8 & 47.8 & 2.76 & 31.4 & 421 \\
\hline
\end{tabular}

Notos: $\quad(1)=$ USDA soil classification system

NA $=$ Not Analyzod/Nol Applicable

TCLP = Toxicity Characteristic Leaching Proceduro (40 CFR Part 261.24)

Soll concontrations are reported on a diy woight basis 
Table 5. Orangeburg Soll (Clay) Dala Summary (PWMP)

Prepared for the Westinghouse Savannah Rlver Company (WSAC). Alken, SC by Sirrine Environmental Consultants, Greenvillo, SC

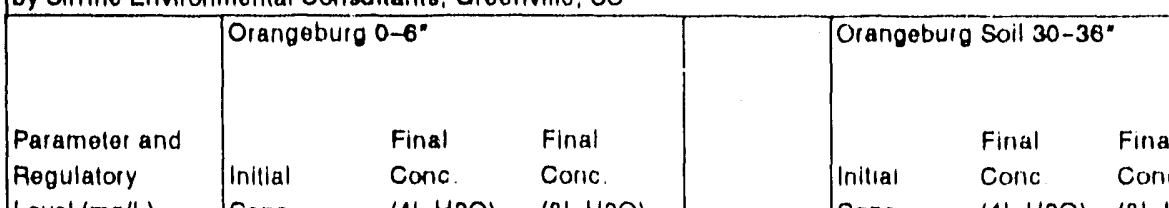

$\begin{array}{lllll}\text { Level (mg/L) } & \text { Conc. } & \text { (4L H2O) (8L H2O) }\end{array}$

Conc (4L H2O) (8L. H2O)

TCLP Inorganics (TCLP Inorganics analysis; $\mathrm{mg} / \mathrm{L}$ )

\begin{tabular}{|l|l|l|l|}
\hline $\mathrm{As}(5.0)$ & $<0.005$ & $<1.0$ & $<1.0$ \\
\hline $\mathrm{Ba}(100.0)$ & 0.250 & $<1.0$ & $<1.0$ \\
\hline $\mathrm{Cd}(1.0)$ & $<0.005$ & $<0.5$ & $<0.5$ \\
\hline $\mathrm{Cr}(5.0)$ & $<0.008$ & $<1.0$ & $<1.0$ \\
\hline $\mathrm{Pb}(5.0)$ & $<0.030$ & $<1.0$ & $<1.0$ \\
\hline $\mathrm{Hg}(0.2)$ & $<0.002$ & $<0.2$ & $<0.2$ \\
\hline $\mathrm{Sg}(1.0)$ & $<0.005$ & $<0.5$ & $<0.5$ \\
\hline $\mathrm{Ag}(5.0)$ & $<0.005$ & $<1.0$ & $<1.0$ \\
\hline
\end{tabular}

$\mid \frac{1.0}{1.0}$

\begin{tabular}{|l|l|l|}
\hline$<0.100$ & $<1.0$ & $<1.0$ \\
\hline $0.28 \theta$ & $<1.0$ & $<1.0$ \\
\hline$<0.005$ & $<0.5$ & $<0.5$ \\
\hline$<0.008$ & $<1.0$ & $<1.0$ \\
\hline$<0.030$ & $<1.0$ & $<1.0$ \\
\hline$<0.002$ & $<0.2$ & $<0.2$ \\
\hline$<0.100$ & $<0.5$ & $<0.5$ \\
\hline$<0.005$ & $<1.0$ & $<1.0$ \\
\hline
\end{tabular}

TCLP Inorganlos (total inorganics analysis; $\mathrm{mg} / \mathrm{kg}$ )

\begin{tabular}{|l|l|l|l|}
\hline As (total) & 1.22 & 60 & 123 \\
\hline $\mathrm{Ba}$ (total) & 3.51 & 1400 & 2900 \\
\hline $\mathrm{Cd}$ (total) & $<0.355$ & 13 & 23 \\
\hline $\mathrm{Cr}$ (total) & 4.43 & 72 & 131 \\
\hline $\mathrm{Pb}$ (total) & $<2.13$ & 63 & 105 \\
\hline $\mathrm{Hg}$ (total) & $<0.100$ & 1.4 & 2.6 \\
\hline $\mathrm{Se}$ (total) & $<0.355$ & 12 & 23 \\
\hline Ag (total) & $<0.355$ & 63 & 120 \\
\hline Ord & & \\
\hline
\end{tabular}

\begin{tabular}{|l|l|l|}
\hline 4.03 & 133 & 406 \\
\hline 32.6 & 2900 & 10000 \\
\hline$<0.355$ & 25 & 68 \\
\hline 39.2 & 213 & 559 \\
\hline$<21.3$ & 129 & 399 \\
\hline$<0.100$ & 2.4 & 6.6 \\
\hline$<3.55$ & 17 & 84 \\
\hline$<3.55$ & 125 & 413 \\
\hline
\end{tabular}

Other Metals (total metals analyis; $\mathrm{mg} / \mathrm{kg}$ )

\begin{tabular}{|c|c|c|c|c|c|c|}
\hline Aluminum & 3900 & 9600 & 15000 & 38000 & 68000 & 175000 \\
\hline Beryllium & $<1.0$ & $<1.0$ & 2.1 & $<1.0$ & $<1.0$ & 10 \\
\hline Calclum & 68 & 290 & 330 & 220 & 420 & 700 \\
\hline Copper & 0.96 & 10 & 20 & 9.1 & 29 & 91 \\
\hline Iron & 2000 & 3600 & 5100 & 25000 & 57000 & 98000 \\
\hline Lithium & 1.5 & 6.8 & 11 & 11 & 19 & 70 \\
\hline Magneslum & 87 & 440 & 620 & 380 & 500 & 1800 \\
\hline Manganese & 89 & 170 & 260 & 39 & 350 & 900 \\
\hline Nickel & 1.8 & 33 & 60 & 9.8 & 76 & 245 \\
\hline Potassium & 51 & 59 & 92 & 240 & 230 & 750 \\
\hline Sodium & 14 & 660 & 660 & 16 & 3400 & 6400 \\
\hline Zinc & 3.7 & 78 & 141 & 15 & 167 & 545 \\
\hline
\end{tabular}

Other Analyses

\begin{tabular}{|c|c|c|c|c|c|c|}
\hline $\mathrm{pH}$ & 5.0 & 0.54 & 6.51 & 5.3 & 6.44 & 6.47 \\
\hline $\operatorname{CEC}(m e q / 100 \mathrm{~g})$ & 0.7 & NA & NA & 2.4 & NA & NA \\
\hline $\begin{array}{l}\text { Total CEC } \\
(\mathrm{meq} / 100 \mathrm{~g})\end{array}$ & 0.9 & NA & $\overline{N A}$ & 3.5 & $\overline{N A}$ & NA \\
\hline 96 org. matter & 1.4 & NA & NA & 0.1 & NA & NA \\
\hline Percont Sand(1) & 90 & NA & NA & 60 & NA & NA \\
\hline Percent Sill(1) & 8 & NA & $\mathrm{NA}$ & 4 & $\mathrm{NA}$ & NA \\
\hline Percent Clay(1) & 2 & NA & $\overline{N A}$ & 36 & NA & $\overline{N A}$ \\
\hline $\begin{array}{l}\text { Diy Blk Donsity } \\
(\mathrm{g} / \mathrm{cu} \mathrm{cm})\end{array}$ & 1.57 & NA & NA & 1.55 & NA & $\widehat{N A}$ \\
\hline $\begin{array}{l}\text { Particlo } \\
\text { Densily } \\
(\mathrm{g} / \mathrm{cu} \mathrm{cm}) \\
\end{array}$ & 2.63 & NA & NA & 2.62 & NA & NA \\
\hline $\begin{array}{l}\text { Gravimetric } \\
\text { Molsture \% }\end{array}$ & 2.84 & 33.5 & 33.4 & 13.3 & 73.7 & 85.7 \\
\hline
\end{tabular}

Notes: $\quad(1)=$ USDA soil classification systom

$N A=$ Not Analyzed/Not Applicablo

TCLP $=$ Toxicily Characteristic Leaching Procedure (40 CFR Pall 261.24)

Soll concentrations are reported on a diy woight basis 


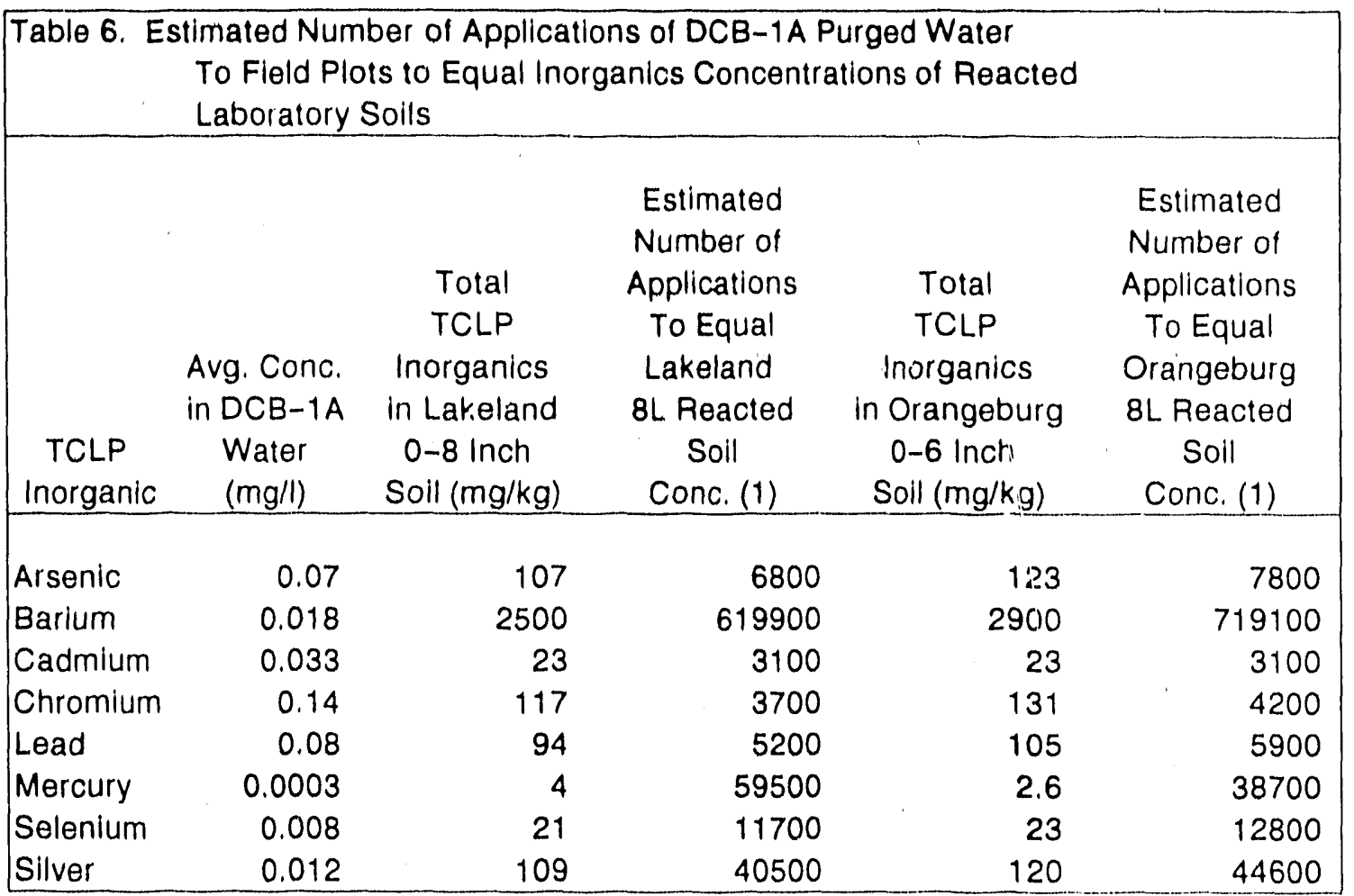

(1) Data are from the Lakeland and Orangeburg 8 liter reactors (Tables 4 and 5).

\section{Assumptions}

+ Application area at each plot $=5.9$ square meters ( 63 square feet)

+ Depth of water/application $=2.54 \mathrm{~cm}$ (1 inch)

+ Volume of water/application $=151$ liters ( 40 gallons)

+ Soll depth that retains all TCLP inorganics $=7.62 \mathrm{~cm}$ ( 3 inches)

+ Soil bulk density $=1.5 \mathrm{grams} /$ cubic centimeter

+ Soll Mass $=674 \mathrm{~kg} / \mathrm{plot}$

\section{Equations}

(DCB-1A Water Conc. $\times$ Vol./Application $\times$ Number of Applications)/Soil Mass $=$ Soll Concentration

where soll conc.$=$ conc, total TCLP inorganics in 8 liter reactor

\# of Applications $=$ (Soil Conc $\times$ Soil Mass)/(Water Conc. $\times$ Vol./Application $)$ 

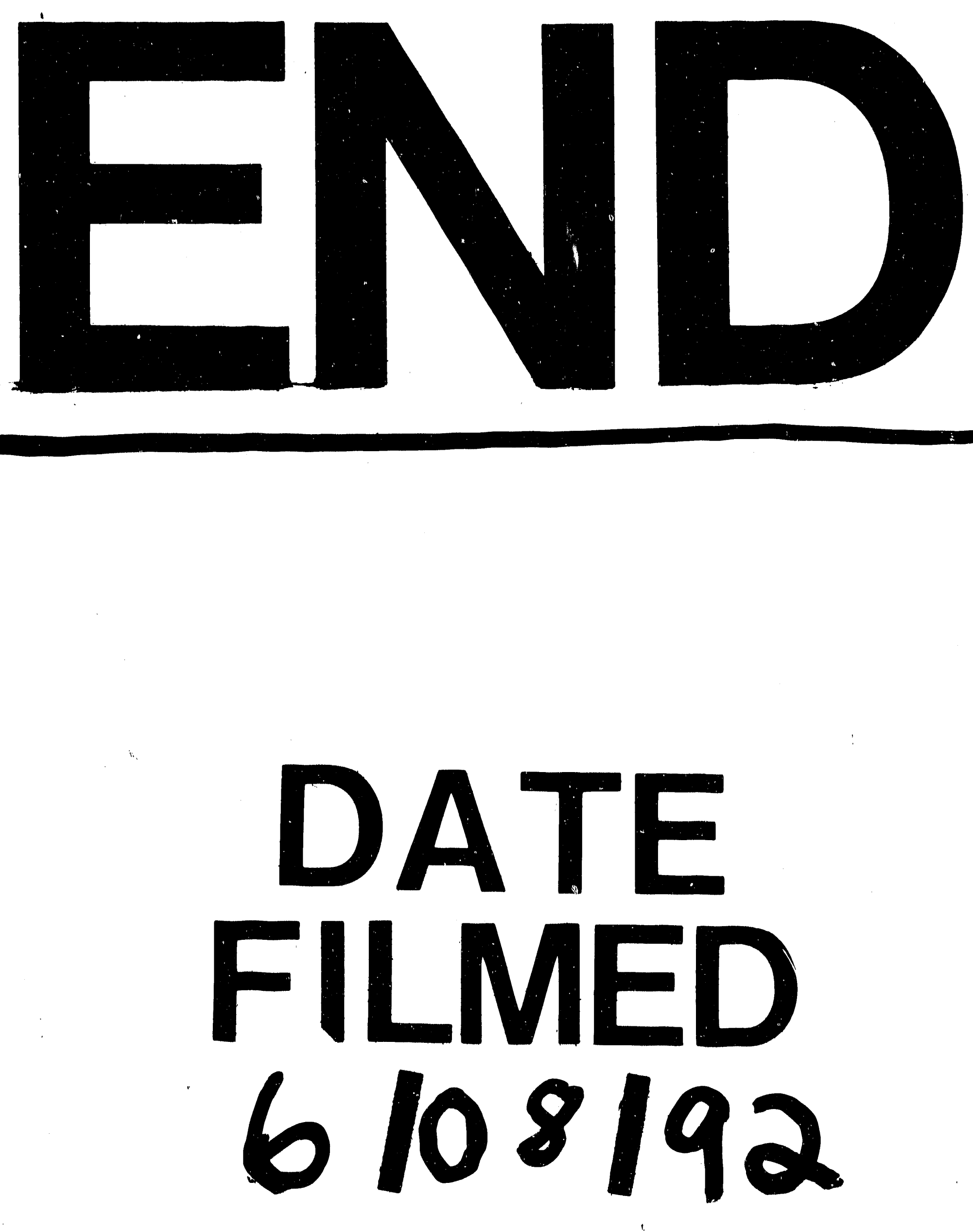
